\title{
Readiness of Future Interpreters to Provide Professional Activity
}

\section{Готовність майбутніх перекладачів до виконання професійної діяльності}

\section{Ernest Ivashkevych}

Ph.D. in Psychology, Lecturer, Department of Practice of English of Rivne State University of the Humanities, the Translator, Rivne (Ukraine)

ORCID ID: https://orcid.org/0000-0001-7219-1086

Researcher ID: F-3865-2019

E-mail: ivashkevych.ee@gmail.com

\section{Ернест Івашкевич}

Кандидат психологічних наук, викладач кафедри практики англійської мови Рівненського державного гуманітарного університету, перекладач, м. Рівне (Україна)

\section{Liana Onufriieva}

Ph.D. in Psychology, Assistant Professor, Professor of the Department of General and Applied Psychology, Head of the Department of General and Applied Psychology, Kamianets-Podilskyi National Ivan Ohiienko University, Kamianets-Podilskyi (Ukraine)

ORCID ID: https://orcid.org/0000-0003-2442-4601

Researcher ID: R-5598-2018

E-mail: kpnu_lab_ps@ukr.net

\section{Ліана Онуфрієва}

Кандидат психологічних наук, доцент, професор кафедри, завідувач кафедри загальної та практичної психології, Кам'янець-Подільський національний університет імені Івана Огієнка, м. Кам'янець-Подільський (Україна)

Address for correspondence, e-mail: kpnu_lab_ps@ukr.net Copyright: (c) Ivashkevych Ernest, Onufriieva Liana

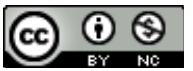
The article is licensed under CC BY-NC 4.0 International (https://creativecommons.org/licenses/by-nc/4.0/)

(C) Ivashkevych Ernest, Onufriieva Liana DOI (article): https://doi.org/10.32626/2227-6246.2020-47.71-92 
DOI: https://doi.org/10.32626/2227-6246.2020-47 2020. випуск 47

The author's contribution of the author: E. Ivashkevych $-50 \%$, L. Onufriieva $-50 \%$. Авторський внесок: Е. Івашкевич - 50\%, Л. Онуфрієва - 50\%.

\section{ABSTRACT}

The purpose of the research is to create a conceptual model of professional development of a translator, as well as to conduct an empirical study to determine the level of readiness of a future specialist to perform a professional activity.

Methods of the research. The following theoretical methods of the research were used to solve the tasks formulated in the article: a categorical method, structural and functional methods, the methods of the analysis, systematization, modeling, generalization. Also in the research we used experimental method, such as ascertaining experiment.

The results of the research. The conceptual model of the professional development of a future translator was constructed in our research. It was stated that that model would necessarily include professional readiness for performing the activity. Willingness is characterized by the different nature of the interconnections of its structural components (a cognitive component knowledge of a foreign language, a linguistic one - linguistic competence, the component of implementation - communication skills). Considering the readiness of a student as a component of person's intercultural communication as a set of individually significant psychological factors of a specialist, we (taking into account the diagnostic goals) have identified the characteristics of different levels of the development of each of the factors of readiness, which we mean as a criterion basis for studying the phenomenon of students' readiness for organizing the process of successful intercultural communication. The first (a cognitive) component is considered in the context of this study as varying levels of foreign language acquisition. In fact, in our opinion, a cognitive component of readiness contains the linguistic competence of the person, as well as his/ her communicative skills and the peculiarities of using them in the process of translation activity.

It was emphasized that a specialist's readiness for professional activity contained three components: a) motivational readiness; b) meaningful readiness; c) operational readiness. Considering that the professional activity of the translator is characterized by axiological orientation, it was stated that the translator's readiness for professional activity would also contain the fourth component, we call it «valuable readiness».

(C) Ivashkevych Ernest, Onufriieva Liana

DOI (article): https://doi.org/10.32626/2227-6246.2020-47.71-92 
Conclusions. The need for creative activity of students of all faculties of foreign philology had mostly been high, and professional qualities which determine the formation of components of readiness for translation are at the stage of intensive forming, such as: the awareness of the need to bring the matter to a logical conclusion, mastering the basic means of translating, orientation in interpersonal relationships. Also, the high level of translation activity of students in each group is fixed at the level of no more than 25\%, which indicates that students are not enough professional.

Thus, the professional development of a person is a holistic, dynamic process well organized in time, characterized primarily by the formation of professional intentions, then - by the acquisition of knowledge and mastery of skills and abilities, and so to a full realization of oneself in creative pedagogical activity. The main contradiction of professional formation is, as a rule, the contradiction between well-developed personality traits and the objective requirements of leading activity, the significance of which is that it largely determines the further development of the individual as a subject of professional activity. Realizing himself / herself in the process of leading activity, the person gradually changes, which leads to the restructuring of the motives of his / her own professional activity, the formation of new personal characteristics, qualities and traits.

Key words: readiness for professional activity, motivational readiness, meaningful readiness, operational readiness, professional growth, the conceptual model of the professional development of a future translator.

\section{Вступ}

Професійне становлення майбутнього перекладача $\epsilon$ складним інтегративним процесом, який передбачає використання різноманітних форм, засобів і методів фасилітативного впливу на особистість студента. 3 метою відбору й обгрунтування доцільності використання таких форм, засобів і методів опишемо концептуальну модель професійного становлення майбутнього перекладача. Ця модель, своєю чергою, вимагає спеціальної розробки, опису й аналізу їі складових у силу, передусім, своєї цілісності, багатокомпонентності та поліфункціональності.

Професійне становлення розглядають як довготривалий процес оволодіння професією. Науковці вважають, що про-

(C) Ivashkevych Ernest, Onufriieva Liana DOI (article): https://doi.org/10.32626/2227-6246.2020-47.71-92 
DOI: https://doi.org/10.32626/2227-6246.2020-47 2020. випуск 47

фесійне становлення може бути представлено двома способами: за схемою процесу (як тимчасова послідовність ступенів, періодів, стадій) (Mykhalchuck, 2018) і за структурою діяльності (як сукупність способів і засобів, дотримання яких один за одним має не тимчасову, а парадигмально-цільову детермінацію) (Максименко, 2005). Окрім цього, під професійним становленням слід розуміти формування професійної компетентності як процес оволодіння засобами розв'язання професійно-педагогічних завдань і задач, а також моделями їх розв'язання тощо.

Проте в науковій літературі не існує єдиної думки щодо професійного становлення майбутнього перекладача. Також потребує спеціальної розробки концептуальна модель професійного становлення фахівця з перекладу, а емпіричних досліджень - готовність майбутнього спеціаліста до виконання професійної діяльності. Ці базові моменти й стали метою нашого дослідження.

Так, зважаючи на проведений теоретико-методологічний аналіз наукової літератури в нашому дослідженні, його завданнями $€$ :

1) описати професійне становлення особистості як цілісний процес, що має свої якісні характеристики й особливості;

2) окреслити процес професійного становлення у зв'язку з формуванням професійної готовності фахівця до виконання майбутньої діяльності;

3) побудувати концептуальну модель професійного становлення майбутнього перекладача;

4) провести емпіричне дослідження готовності майбутнього спеціаліста до виконання професійної діяльності.

Якщо враховувати позиції соціономічного підходу в психології (Онуфрієва, 2013), то професійне становлення спрямоване, насамперед, на становлення особистості фахівця в парадигмі кроскультурного простору. Тому професійне становлення майбутнього фахівця постає, передусім, як про(C) Ivashkevych Ernest, Onufriieva Liana

DOI (article): https://doi.org/10.32626/2227-6246.2020-47.71-92 
цес формування студента як носія загальної та професійної культури, що забезпечує його повноцінне функціонування в навколишньому світі й професійній діяльності (Onufriieva, 2017).

Слід ураховувати, що процес професійного становлення щільно пов'язаний із формуванням професійної готовності фахівця до виконання майбутньої діяльності. До структури професійної готовності входять позитивне ставлення індивіда до своєї майбутньої професії, досить стійкі мотиви виконання майбутньої діяльності, професійно значущі якості особистості, професійні знання, уміння і навички, а також певний досвід їх застосування на практиці. Отже, для професійного становлення особистості важливим є опанування майбутніми фахівцями нормами, еталонами професії, необхідними професійними особистісними якостями, знаннями й уміннями, які потрібні фахівцеві для успішного розв'язання завдань професійної діяльності, формування мотиваційно-ціннісного ставлення до своєї професії, усвідомлення i реалізації зони свого найближчого професійного розвитку; готовність здійснювати диференційовану оцінку виконаної діяльності; поєднання професійної відкритості, здатності до навчання і самостійних творчих пошуків.

Ми розглядатимемо професійне становлення майбутнього перекладача з позицій культурологічного підходу як процес формування особистісно-професійної позиції індивіда з урахуванням усього різноманіття суб'єктивних і об'єктивних чинників, що передбачає реалізацію стратегій управління особистісними ресурсами, потрібними для здійснення професійної діяльності на фаховому рівні. Професійне становлення майбутнього перекладача також передбачає формування особистісно значущої позиції, яка розуміється нами як система домінуючих ціннісно-смислових ставлень фахівця до соціокультурного оточення, самого себе і своєї діяльності.

(C) Ivashkevych Ernest, Onufriieva Liana DOI (article): https://doi.org/10.32626/2227-6246.2020-47.71-92 
Концептуальна модель професійного становлення майбутнього перекладача, на нашу думку, обов'язково включатиме професійну готовність до виконання діяльності. Формування готовності до здійснення іншомовного спілкування та перекладу стає необхідною передумовою підготовки фахівців, які володіють іноземною мовою, вміють увійти в контакт із представниками іншої культури. У психологічних дослідженнях (Кочубей, 2016) готовність до здійснення іншомовного спілкування та перекладу розглядається як інтегральне особистісне новоутворення, що передбачає високий рівень знань іноземної мови, лінгвокраїнознавства, а також володіння фахівцем потрібними комунікативними вміннями і навичками. Психологи відносять стан готовності переважно до інтелектуально-вольових станів, оскільки його провідними характеристиками є прагнення успішно розв'язувати задачі саморозвитку, самовдосконалення, виявляти творчість і впевненість у розвитку своїх професійних здібностей, які можна розглядати як необхідну умову здійснення вольового процесу прийняття професійно значущих рішень, управління своєю поведінкою та діями з метою досягнення мети діяльності. Стан готовності майбутнього перекладача до саморозвитку та самореалізації ми розглядаємо як прагнення особистості до подолання внутрішніх протиріч, станів тривожності та когнітивного дисонансу, творчої реалізації планів і програм самоздійснення. Готовність майбутнього перекладача до саморозвитку визначається загальними і спеціальними знаннями, вміннями, навичками, психічними процесами, станами і властивостями особистості, врешті-решт - відповідальністю за результати самовдосконалення й особистісного зростання.

Готовність характеризується різним характером взаємозв'язків її структурних компонентів (когнітивного - знання іноземної мови, лінгвокраїнознавчого - лінгвокраїнознавча компетенція, реалізаційного - комунікативні вміння). Роз(C) Ivashkevych Ernest, Onufriieva Liana

DOI (article): https://doi.org/10.32626/2227-6246.2020-47.71-92 
глядаючи готовність студента до інтеркультурної комунікації як сукупність окремих значущих для фахівця показників, ми (з урахуванням діагностичних цілей) визначили характеристику різних рівнів розвитку кожного з показників готовності, які розглядаємо як критеріальну основу для дослідження феномену готовності студентів до здійснення успішної інтеркультурної комунікації. Перший (когнітивний) показник розглянуто в контексті цього дослідження як різний рівень опанування іноземною мовою. Фактично, когнітивний показник готовності, на нашу думку, вміщує лінгвокраїнознавчу компетенцію особистості, а також комунікативні вміння фахівця й особливості їх використання у перекладацькій діяльності.

Також важливо наголосити, що стан готовності до здійснення іншомовного спілкування слід віднести до інтелектуально-вольових станів особистості, оскільки його провідними компонентами є прагнення успішно розв'язувати комунікативні задачі, виявляти творчість і впевненість у своїх комунікативних здібностях, які, своєю чергою, можна розглядати як характеристику мисленнєвого і моторно-вольового процесу прийняття рішення, свідомого управління власною поведінкою під час прийняття та реалізації рішень. Формування стану готовності до здійснення іншомовного спілкування означає створення у людини системи мотивів, ставлень, настановлень, які, актуалізуючись у разі необхідності, забезпечують для майбутнього перекладача можливість ефективно виконувати свої функції у процесі професійної діяльності.

Готовність до здійснення перекладацької діяльності передбачає наявність у фахівця професійної компетентності, тобто, знання лінгвістичного матеріалу, володіння способами, прийомами і засобами актуалізації цих знань у конкретній ситуації, високий рівень розвитку навичок аудіювання, говоріння, письма іноземною мовою. Готовність фахівця до

(C) Ivashkevych Ernest, Onufriieva Liana DOI (article): https://doi.org/10.32626/2227-6246.2020-47.71-92 
DOI: https://doi.org/10.32626/2227-6246.2020-47

здійснення перекладацької діяльності передбачає здатність спеціаліста виявляти високий рівень мисленнєвої та пізнавальної активності, самостійності й самоорганізації у розв'язанні комунікативно-пізнавальних завдань i задач. Отже, різний рівень опанування системою необхідних знань, умінь і навичок, різний ступінь активності й самостійності особистості визначають і різний ступінь готовності до прийняття перекладачем самостійних виважених рішень і здійснення самостійних дій.

Для нас близька точка зору, що має місце в психологічній літературі, а саме те, що готовність фахівця до здійснення професійної діяльності вміщує три компоненти: а) мотиваційну готовність; б) змістову готовність; в) операційну готовність. Зважаючи на те, що професійна діяльність перекладача характеризується аксіологічною спрямованістю, ми вважатимемо, що готовність перекладача до здійснення професійної діяльності вміщуватиме ще й четвертий компонент, а саме - «ціннісну готовність».

Прийнявши за другий (аксіологічний) показник готовності студентів до інтеркультурної комунікації лінгвокраїнознавчі знання, вміння та навички, ми також мали на увазі, що до зазначеного аксіологічного показника повинні входити ціннісні орієнтації, які великою мірою характеризуватимуть морально-ціннісне ставлення студентів до явищ оточуючої дійсності. Для перекладача аксіологічний показник готовності до здійснення перекладацької діяльності $€$ домінуючим, адже ціннісні орієнтації фахівця визначають мотивацію діяльності суб'єкта, спрямованість його інтересів і прагнень.

Концептуальна модель професійного становлення майбутнього перекладача також уміщує професійну компетентність, яка, своєю чергою, включає певні окремі компетентності, що й забезпечують здатність перекладача до здійснення професійної діяльності. При цьому слід зазначити, що професійна компетентність є сукупністю взаємопов'язаних (C) Ivashkevych Ernest, Onufriieva Liana

DOI (article): https://doi.org/10.32626/2227-6246.2020-47.71-92 
знань, якостей, компонентів досвіду, характеристик здібностей особистості, що задаються стосовно процесів професійної діяльності. Також професійне становлення перекладача, на нашу думку, значною мірою залежить від сформованості у фахівця перекладацької свідомості. Концептуальну модель професійного становлення майбутнього перекладача зображено на рис. 1.

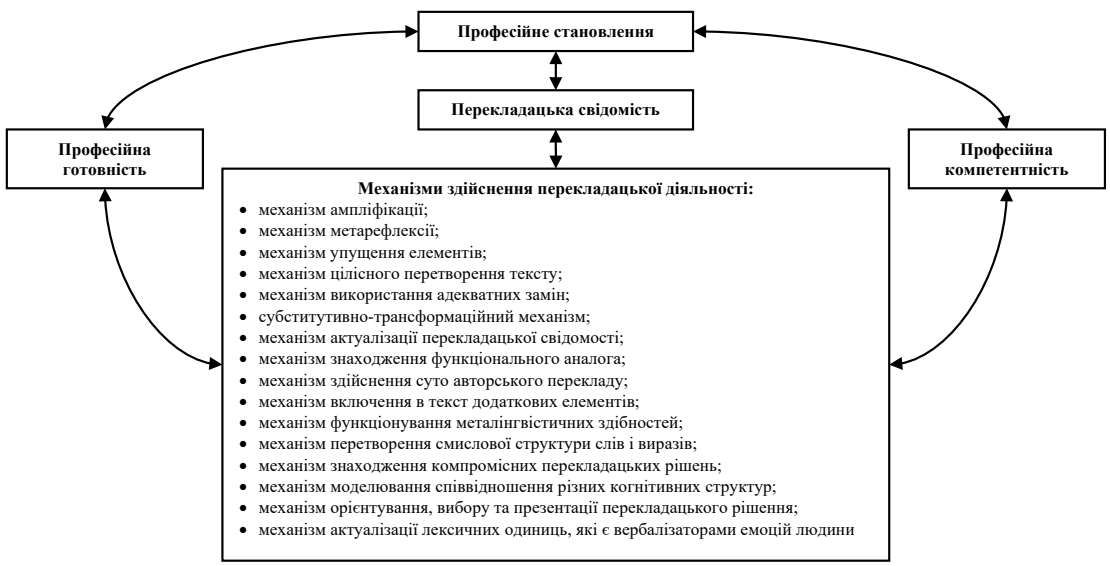

Puc. 1. Концептуальна модель професійного становлення майбутнього перекладача

\section{Методи дослідження}

Для розв'язання поставлених у статті завдань використовувалися такі теоретичні методи дослідження: категоріальний, структурно-функціональний, аналіз, систематизація, моделювання, узагальнення, а також експерилентальний летод: констатувальний експеримент. Експериментальне дослідження з метою виявлення динаміки професійного становлення майбутнього перекладача тривало упродовж 2016-2017 рр. У ньому брали участь 303 студенти сформованих нами експериментальних і контрольних груп факультетів іноземної філології:

(C) Ivashkevych Ernest, Onufriieva Liana DOI (article): https://doi.org/10.32626/2227-6246.2020-47.71-92 
DOI: https://doi.org/10.32626/2227-6246.2020-47

1) експериментальні групи (150 студентів):

- E1 - 38 студентів II курсу Рівненського державного гуманітарного університету;

- E2 - 40 студентів III курсу Львівського державного університету безпеки життєдіяльності;

- E3 - 35 студентів II курсу Східноєвропейського національного університету імені Лесі Українки;

- E4 - 37 студентів III курсу Кам'янець-Подільського національного університету імені Івана Огієнка;

2) контрольні групи (153 студенти):

- К1 - 39 студентів II курсу Рівненського державного гуманітарного університету;

- К2 - 35 студентів III курсу Львівського державного університету безпеки життєдіяльності;

- К3 - 41 студент II курсу Східноєвропейського національного університету імені Лесі Українки;

- К4 - 38 студентів III курсу Кам'янець-Подільського національного університету імені Івана Огієнка.

Групи були сформовані за методом рандомізації (технологія парного дизайну). За критерї професійного становлення майбутніх перекладачів нами було прийнято високий рівень готовності студентів до виконання перекладацької діяльності, високий рівень сформованості професійної компетентності та перекладацької свідомості тощо.

Отже, на даному етапі дослідження ми вивчали рівень готовності майбутніх фахівців до виконання професійної діяльності. У якості методологічного інструментарію для першого етапу дослідження нами було обрано:

1) методику «Хто Я?» (Кун, Макпартленд, 2017).

2) техніки «Мій шлях у професію» та «Піраміда професійного зростання» (розроблені М. Ю. Варбан та О. Б. Старовойтенко й адаптовані нами для майбутніх перекладачів) (Варбан, 1998).

(C) Ivashkevych Ernest, Onufriieva Liana

DOI (article): https://doi.org/10.32626/2227-6246.2020-47.71-92 


\section{Результати та дискусії}

Усвідомлення студентами необхідності актуалізації та реалізації своїх здібностей у плані виконання перекладацької діяльності розраховувалося за сумою позитивних і негативних відповідей на запропоновані нами запитання інтерв'ю. Отримані результати наведено у табл. 1.

таблищя 1

Уявлення студентів експериментальних і контрольних груп щодо необхідності самоактуалізації в навчанні та майбутній професійній діяльності (у \%, констатувальне дослідження)

\begin{tabular}{|c|c|c|}
\hline Групи & $\begin{array}{c}\text { Вважають } \\
\text { самоактуалізацію } \\
\text { необхідою }\end{array}$ & $\begin{array}{c}\text { Вважають } \\
\text { самоактуалізацію } \\
\text { непотрібною }\end{array}$ \\
\hline Експериментальні & & \\
\hline Е1 & 60,36 & 39,64 \\
\hline Е2 & 62,12 & 37,88 \\
\hline Е3 & 58,34 & 41,66 \\
\hline Е4 & 61,07 & 38,93 \\
\hline Контрольні & & 37,89 \\
\hline К1 & 62,11 & 36,82 \\
\hline К2 & 63,18 & 42,74 \\
\hline К3 & 57,26 & 40,96 \\
\hline К4 & 59,04 & \\
\hline
\end{tabular}

Як бачимо з табл. 1, третина студентів кожної групи дала негативну відповідь. Проте такий стан речей може бути пов'язаний iз бажанням відійти від звичних, шаблонних відповідей, бажанням звернути на себе увагу й оригінально обгрунтувати свою точку зору. Тим не менш, більшість студентів у всіх групах підтверджують необхідність самоактуалізації. Порівняння результатів за методом $\varphi$-критерію Фішера не показало значущих відмінностей ( $\mathrm{F}=0,73$ в $\mathrm{E} 1$;

(C) Ivashkevych Ernest, Onufriieva Liana DOI (article): https://doi.org/10.32626/2227-6246.2020-47.71-92 
DOI: https://doi.org/10.32626/2227-6246.2020-47

$\mathrm{F}=0,71$ в $\mathrm{E} 2 ; \mathrm{F}=0,68$ в $\mathrm{E} 3 ; \mathrm{F}=0,67$ в $\mathrm{E} 1 ; \mathrm{F}=0,75$ у $\mathrm{K} 1$; $\mathrm{F}=0,69$ у $\kappa 2 ; \mathrm{F}=0,74$ у $\kappa 3 ; \mathrm{F}=0,73$ у $\kappa 4$ ) між студентами експериментальних і контрольних груп.

Коли ми запитали студентів, які, як правило, у навчальній діяльності не демонструють здатності до самоактуалізаціï, в чому причина такого становища, то 20,44\% респондентів групи E1, 21,32\% - E2, 31,44\% - E3, 32,82\% - E4, $25,46 \%-\mathrm{K} 1,28,04 \%-\mathrm{K} 2,21,02 \%$, - К3 і $28,44 \%-$ К 3 деякою образою відповіли, що викладачі, переважно, слухають те, що студенти хочуть висловити з певного питання, але не стимулюють їх до самостійності й активності. Також майже половина студентів кожної групи стверджували під час інтерв'ю, що лише деякі викладачі заохочують їхню ініціативу, але уточнюють: «залежно від навчальної дисципліни». Понад $60 \%$ студентів усіх груп зазначали, що прагнення до дискусій, які призводять до відхилення від теми, та звернення до тих питань, які їх дійсно цікавлять, а також прояви ініціативи на заняттях заохочуються досить рідко. Близько $20 \%$ студентів кожної групи на це запитання відповіли: «Викладачі частіше ігнорують ініціативу, ніж заохочують», що, в принципі, також не фасилітує становлення готовності студентів до виконання професійної діяльності.

Отже, отримані результати свідчать про те, що мікроклімат на факультетах іноземної філології в різних закладах вищої освіти загалом є сприятливим для прояву студентами активності й ініціативності та розкриття себе як творчого суб’єкта перекладацької діяльності. Проте деякі моменти вельми насторожують.

Так, якщо співвіднести думки студентів із думками викладачів, різниця виявляється суттєвою (понад $30 \%$ ). Можна припустити, що викладачі, порівняно зі студентами, мають різне уявлення щодо критеріїв самостійності, соціальної свободи, соціально бажаних відповідей, толерантності, терплячості щодо думок інших (навіть якщо викладачі й (C) Ivashkevych Ernest, Onufriieva Liana

DOI (article): https://doi.org/10.32626/2227-6246.2020-47.71-92 
не погоджуються з цими думками). Студенти ж ставляться до проявів ініціативності на заняттях критичніше, вони меншою мірою зорієнтовані на соціальне схвалення у своїх відповідях, є більш незалежними та демократичними в обгрунтуванні власних думок і тверджень.

Достатньо великий відсоток відповідей викладачів (близько 40\%) свідчить про їх негативне ставлення до впровадження нестандартних підходів на заняттях і щодо оригінальності у виконанні студентами завдань. Ми бачимо в такій ситуації деяке протиріччя, оскільки підготовка i piвень сформованості професійної компетентності викладачів закладів вищої освіти повинні передбачати неабиякий рівень майстерності та володіння предметом, який ними викладається, на рівні імпровізації, i, як наслідок, заохочення викладачами студентів до виконання професійної діяльності на належному рівні.

Отже, більшість опитаних студентів і викладачів переконані в тому, що чим простішою й одноріднішою є професійна діяльність, яка виконується людиною, чим меншим є простір прояву активності особистості, тим більшою мірою гальмуватиметься становлення студента і як професіонала, i як особистості.

На даному підетапі дослідження нами було проаналізовано показники самоактуалізації, а також сформованість у студентів компонентів готовності до виконання перекладацької діяльності.

Показники самоактуалізації студентів ми отримали за допомогою тесту САМОАЛ (Шкала самоактуалізації, 2019). Отримані результати свідчать про те, що студенти усіх груп характеризуються середнім рівнем самоактуалізації (від 70\% до 80\% студентів мають рівень самоактуалізації не більше $48 \%$ ), знижений і вище середнього рівні представлені однаковою мірою у респондентів усіх груп (у середньому значення за самоактуалізацією - до 20\%), низький і високий рівні

(C) Ivashkevych Ernest, Onufriieva Liana DOI (article): https://doi.org/10.32626/2227-6246.2020-47.71-92 
DOI: https://doi.org/10.32626/2227-6246.2020-47 2020. випуск 47

майже зовсім не представлені у студентів. Тому ми можемо припустити, що студенти мають неабиякий особистісний потенціал, який фасилітуе їх здатність до самоактуалізації, однак на даний момент цей потенціал не є реалізованим у близько 70\% студентів - учасників дослідження (табл. 2).

Таблиця 2

Результати студентів експериментальних і контрольних груп за рівнями самоактуалізації за тестом САМОАЛ (у \%, констатувальне дослідження)

\begin{tabular}{|c|c|c|c|c|c|c|c|c|}
\hline \multirow{2}{*}{$\begin{array}{c}\text { Рівень само- } \\
\text { актуалізації } \\
\text { у студентів }\end{array}$} & \multicolumn{4}{|c|}{$\begin{array}{c}\text { Експериментальні } \\
\text { групи } \\
\end{array}$} & \multicolumn{4}{|c|}{ Контрольні групи } \\
\hline & E1 & $\mathbf{E 2}$ & E3 & $\mathbf{E 4}$ & К1 & К2 & К3 & К4 \\
\hline Низький & 9,48 & 10,09 & 12,21 & 11,13 & 14,02 & 96 &, 21 & 0,97 \\
\hline $\begin{array}{l}\text { Ниж } \\
\text { серед }\end{array}$ & 15,24 & 13,18 & 14,60 & 14,25 & 13,12 & 14,82 & 15,94 & 16,98 \\
\hline Середній & 3,01 & 47,32 & 46,54 & 47,25 & 45,16 & 4 & 8,12 & 44,04 \\
\hline $\begin{array}{l}\text { Вищий } \\
\text { середнього }\end{array}$ & 17,35 & 15,26 & 16,58 & 17,21 & 15,45 & 18,31 & 19,02 & 16,94 \\
\hline Високий & 9,92 & 14,15 & 10,07 & 10,16 & 12,25 & 9,67 & 10,71 & 11,07 \\
\hline
\end{tabular}

Результати готовності студентів до виконання професійної діяльності наведено у табл. 3. Виходячи з отриманих результатів, лише $30 \%$ студентів кожної групи мають високий рівень готовності до виконання перекладацької діяльності. Отже, переважна більшість студентів усвідомлюють власні цілі, бажання й інтереси у професійній діяльності, але у них не сформовані навички перекладу, і це не дає їм змоги повною мірою самостійно виконувати професійну діяльність.

(C) Ivashkevych Ernest, Onufriieva Liana

DOI (article): https://doi.org/10.32626/2227-6246.2020-47.71-92 
Розподіл студентів експериментальних і контрольних груп за компонентами готовності (високим рівнем) до виконання професійної діяльності (у балах, за результатами факторного аналізу, констатувальне дослідження)

\begin{tabular}{|c|c|c|c|c|c|c|c|c|}
\hline \multirow{2}{*}{\begin{tabular}{|c|} 
Високий \\
рівень \\
готовності \\
студентів до \\
виконання \\
професійної \\
діяльності
\end{tabular}} & \multicolumn{4}{|c|}{$\begin{array}{c}\text { Експериментальні } \\
\text { групи }\end{array}$} & \multicolumn{4}{|c|}{ Контрольні групи } \\
\hline & E1 & E2 & E3 & E4 & К1 & К2 & K3 & К4 \\
\hline $\begin{array}{l}\text { Мотиваційна } \\
\text { готовність }\end{array}$ & 0,3142 & 0,2846 & 0,2714 & 0,3561 & 0,3428 & 0,2518 & 0,2248 & 0,2645 \\
\hline $\begin{array}{l}\text { Змістова } \\
\text { готовність }\end{array}$ & 0,3848 & 0,4256 & 0,3025 & 0,3744 & 0,3841 & 0,4026 & 0,4155 & 0,3949 \\
\hline $\begin{array}{l}\text { Операційна } \\
\text { готовність }\end{array}$ & 0,2490 & 0,2641 & 0,2711 & 0,3112 & 0,2518 & 0,2002 & 0,2848 & 0,3142 \\
\hline $\begin{array}{l}\text { Ціннісна } \\
\text { готовність }\end{array}$ & 0,2105 & 0,1962 & 0,2264 & 0,2041 & 0,2348 & 0,2140 & 0,2516 & 0,2003 \\
\hline $\begin{array}{l}\text { Композитна } \\
\text { оцінка } \\
\text { готовності }\end{array}$ & 0,2944 & 0,2826 & 0,2453 & 0,2545 & 0,2691 & 0,2893 & 0,2764 & 0,2831 \\
\hline
\end{tabular}

Аналіз результатів спостережень за сформованістю у студентів компонентів готовності до виконання перекладацької діяльності проводився за допомогою щоденника спостережень. Результати наведено у табл. 4. 
Розподіл студентів експериментальних і контрольних груп за компонентами готовності до виконання професійної діяльності (у \%, констатувальне дослідження)

\begin{tabular}{|l|c|c|c|c|c|c|c|c|}
\hline $\begin{array}{l}\text { Показники готовності } \\
\text { до виконання } \\
\text { перекладацької } \\
\text { діяльності }\end{array}$ & \multicolumn{2}{|c|}{$\begin{array}{c}\text { Експериментальні } \\
\text { групи }\end{array}$} & \multicolumn{3}{|c|}{ Контрольні групи } \\
\cline { 2 - 9 } & $\mathbf{E 1}$ & $\mathbf{E 2}$ & $\mathbf{E 3}$ & $\mathbf{E 4}$ & $\mathbf{K 1}$ & $\mathbf{K 2}$ & $\mathbf{K 3}$ & $\mathbf{K 4}$ \\
\hline $\begin{array}{l}\text { Високий рівень потре- } \\
\text { би у виконанні пере- } \\
\text { кладацької діяльності }\end{array}$ & 38,25 & 34,19 & 35,39 & 39,01 & 34,16 & 38,47 & 33,02 & 34,56 \\
\hline $\begin{array}{l}\text { Передбачення май- } \\
\text { бутнього результату } \\
\text { в перекладацькій ді- } \\
\text { яльності (високий рі- } \\
\text { вень) }\end{array}$ & 24,22 & 23,49 & 24,05 & 26,51 & 27,48 & 25,23 & 26,12 & 27,40 \\
\hline $\begin{array}{l}\text { Усвідомлення необ- } \\
\text { хідності формування } \\
\text { мети перекладацької } \\
\text { діяльності (високий } \\
\text { рівень) }\end{array}$ & 41,84 & 39,22 & 42,55 & 40,04 & 38,58 & 31,44 & 37,47 & 31,16 \\
\hline $\begin{array}{l}\text { Високий рівень здійс- } \\
\text { нення перекладацької } \\
\text { діяльності }\end{array}$ & 25,06 & 23,02 & 22,49 & 25,11 & 24,01 & 28,46 & 25,61 & 23,17 \\
\hline $\begin{array}{l}\text { Орієнтування у міжо- } \\
\text { собистісних стосун- } \\
\text { ках у перекладацькій } \\
\text { діяльності (високий } \\
\text { рівень) }\end{array}$ & 34,58 & 31,27 & 35,48 & 31,03 & 34,49 & 36,12 & 37,42 & 38,94 \\
\hline
\end{tabular}

\section{Висновки}

Потреба у творчій діяльності в студентів усіх факультетів іноземної філології є переважно високою, а професійні якості, що зумовлюють формування компонентів готовності до здійснення перекладацької діяльності, знаходяться на () Ivashkevych Ernest, Onufriieva Liana

DOI (article): https://doi.org/10.32626/2227-6246.2020-47.71-92 
стадії становлення, а саме: усвідомлення необхідності доведення справи до логічного завершення, володіння базовими засобами здійснення перекладацької діяльності, орієнтування в міжособистісних стосунках. Також високий рівень здійснення перекладацької діяльності у студентів кожної групи фіксується на рівні не більше $25 \%$, що свідчить загалом про зовсім недостатню професіоналізацію студентів.

Отже, професійне становлення особистості - це цілісний, динамічно розгорнений у часі процес, який характеризується, передусім, формуванням професійних намірів, потім набуттям знань та оволодінням уміннями та навичками, i так до повної реалізації себе у творчій педагогічній діяльності. Основним протиріччям професійного становлення є, як правило, протиріччя між сформованими властивостями особистості й об'єктивними вимогами провідної діяльності, значення якої полягає в тому, що вона великою мірою зумовлює подальший розвиток індивіда як суб’єкта професійної діяльності. Отже, реалізуючи себе у провідній діяльності, особистість поступово змінюється, що призводить до перебудови мотивів професійної діяльності, формування нових для людини особистісних властивостей, якостей і характеристик.

\section{Література}

Варбан М. Ю. Рефлексия профессионального становления в студенческие годы: дис. ... канд. психол. наук: 19.00.01. Самара, 1998. $181 \mathrm{c.}$

Кочубей О. С. Психологічні чинники становлення перекладацької компетентності майбутніх філологів: дис. ... канд. психол. наук: 19.00.07. Київ, 2016. 241 с.

Кун М., Макпартленд Т. Тест «Кто Я?». 2017. URL : vsetesti.ru/424.

Максименко С. Д. Розвиток особистості - розгортання чи новоутворення? Від самопізнання - до своєї професії. Шкільний світ. Психолог. 2005. № 1. С. 15-18.

Онуфрієва Л. А. Формування професіоналізму і психологічна підготовка майбутніх фахівців соціономічних професій. Вісник Харківського національного університету імені В. Н. Каразіна. Серія

(C) Ivashkevych Ernest, Onufriieva Liana

DOI (article): https://doi.org/10.32626/2227-6246.2020-47.71-92 
DOI: https://doi.org/10.32626/2227-6246.2020-47

«Психологія». Харків : Харківський національний університет імені В. Н. Каразіна, 2013. № 1046. Вип. 51. С. 161-165.

Тест САMOAЛ. 2019. URL : psytests.org/shostrom/samoal-run.html.

Mykhalchuck, N. O. (2018). Psychological peculiarities of the organization of effective interpersonal interaction in children's social groups. Mariya Chepil, Oresta Karpenko, Joanna Konashewska (Eds.). Topical issues of future teachers training in Ukraine, (pp. 98-109). Lublin : Wydawnictwo Uniwersytetu Marii Curie-Sklodowskiej.

Onufriieva, L. A. (2017). The Psychology of Professional Realization of a Future Specialist's Personality: Theoretical and Methodological Aspect. Monograph. Rzeszyw : BonusLiber. 194 s. ISBN 978-83-6544183-6.

\section{References}

Varban, M. Yu. (1998). Refleksiia professionalnogo stanovleniia v studencheskiie gody [Reflection of the professional development in students' years]. Candidate's thesis in Psychology. Samara [in Russian].

Kochubei, O. S. (2016). Psykholohichni chynnyky stanovlennia perekladatskoi kompetentnosti maibutnikh filolohiv [Psychological factors of the development of translational competence of future philologists]. Candidate's thesis in Psychology. Kyiv [in Ukrainian].

Kuhn, M., \& McPartland, T. (2017). Test «Kto Ya?» [Test «Who am I?»]. Retrieved from vsetesti.ru/424 [in Russian].

Maksymenko, S. D. (2005). Rozvytok osobystosti - rozhortannia chy novoutvorennia? Vid samopiznannia - do svoiei profesii. [The development of the personality - deployment or new formation? From self-knowledge - to his/her profession]. Shkilnyi svit. Psykholoh School world. Psychologist, 1, 15-18 [in Ukrainian].

Onufriieva, L. A. (2013). Formuvannia profesionalizmu i psykholohichna pidhotovka maibutnikh fakhivtsiv sotsionomichnykh profesii [The development of professionalism and psychological training of future specialists of sociological professions]. Visnyk Kharkivskoho Natsionalnoho Universytetu imeni $V$. N. Karazina - Bulletin of V. N. Karazin Kharkiv National University, 1046 (51), 161-165. Kharkiv : Kharkivskyi natsionalnyi universytet imeni V. N. Karazina [in Ukrainian].

Test SAMOAL [Test SAMOAL]. (2019). Retrieved from psytests.org/ shostrom/samoal-run.html [in Ukrainian].

Mykhalchuck, N. O. (2018). Psychological peculiarities of the organization of effective interpersonal interaction in children's social groups. Mariya Chepil, Oresta Karpenko, Joanna Konashewska (Eds.). Topi-

(C) Ivashkevych Ernest, Onufriieva Liana

DOI (article): https://doi.org/10.32626/2227-6246.2020-47.71-92 http://journals.uran.ua/index.php/2227-6246 
DOI: https://doi.org/10.32626/2227-6246.2020-47 2020. ВИПУСК 47

cal issues of future teachers' training in Ukraine, (pp. 98-109). Lublin : Wydawnictwo Uniwersytetu Marii Curie-Sklodowskiej.

Onufriieva, L. A. (2017). The Psychology of Professional Realization of a Future Specialist's Personality: Theoretical and Methodological Aspect. Rzeszyw : BonusLiber. ISBN 978-83-65441-83-6.

Івашкевич Ернест, Онуфрієва Ліана. Готовність майбутніх перекладачів до виконання професійної діяльності

\section{АНОТАЦІЯ}

Метою дослідження була розробка концептуальної моделі професійного становлення фрахівця з перекладу, а також проведення емпіричного дослідження з ціллю з'ясування рівня готовності майбутнього спеціаліста до виконання професійної діяльності.

Для розв'язання поставлених у статmі завдань використано такі теоретичні методи дослідження: категоріальний, структурно-функціональний, аналіз, систематизація, моделювання, узагальнення, а також експериментальний метод: констатувальний експеримент.

У дослідженні побудовано концептуальну модель професійного становлення майбутнього перекладача. Зазначено, що ия модель обов'язково включатиме професійну готовність до виконання діяльності. Готовність характеризується різним характером взаємозв'язків ії структурних компонентів (когнітивного - знання іноземної мови, лінгвокраїнознавчого - лінгвокраїнознавча компетенція, реалізаційного - комунікативні вміння). Розглядаючи готовність студента до інтеркультурної комунікації як сукупність окремих значущих для фрахівця показників, ми (з урахуванням діагностичних цілей) визначили характеристику різних рівнів розвитку кожного з показників готовності, які розглядаємо як критеріальну основу для дослідження феномену готовності студентів до здійснення успішної інтеркультурної комунікації. Перший (когнітивний) показник розглянуто в контексті нашого дослідження як різний рівень опанування іноземною мовою. Фактично, когнітивний показник готовності, на нашу думку, вмішує лінгвокраїнознавчу компетенцію особистості, а також комунікативні вміння фрахівця й особливості їх використання у перекладацькій діяльності.

Наголошено, що готовність фрахівця до здійснення професійної діяльності вмішує три компоненти: а) мотиваційну готовність; б) змістову готовність; в) операційну готовність. Зважаючи на те, що професійна

(C) Ivashkevych Ernest, Onufriieva Liana DOI (article): https://doi.org/10.32626/2227-6246.2020-47.71-92 
DOI: https://doi.org/10.32626/2227-6246.2020-47

діяльність перекладача характеризується аксіологічною спрямованістю, зазначено, що готовність перекладача до здійснення професійної діяльності вміщуватиме ще й четвертий компонент, а саме - «ціннісну готовність».

Висновки. Потреба в творчій діяльності у студентів усіх факультетів іноземної філології є переважно високою, а професійні якості, що зумовлюють формування компонентів готовності до здійснення перекладацької діяльності, знаходяться на стадії становлення, а саме: усвідомлення необхідності доведення справи до логічного завершення, володіння базовими засобами здійснення перекладацької діяльності, орієнтування в міжособистісних стосунках. Також високий рівень здійснення перекладацької діяльності у студентів кожної групи фіксується на рівні не більше 25\%, що свідчить загалом про зовсім недостатню професіоналізацію студентів.

Отже, професійне становлення особистості - це цілісний, динамічно розгорнений у часі прочес, який характеризується, передусім, формуванням професійних намірів, потім - набуттям знань та оволодінням уміннями й навичками, і так до повної реалізації себе у творчій педагогічній діяльності. Основним протиріччям професійного становлення є, як правило, протиріччя між сформованими властивостями особистості й об'єктивними вимогами провідної діяльності, значення якої полягає в тому, що вона великою мірою зумовлює подальший розвиток індивіда як суб'єкта професійної діяльності. Реалізуючи себе у провідній діяльності, особистість поступово змінюється, що призводить до перебудови мотивів профресійної діяльності, формування нових для людини особистісних властивостей, якостей і характеристик.

Ключові слова: готовність до виконання професійної діяльності, мотиваційна готовність, змістова готовність, операційна готовність, професійне становлення, концептуальна модель професійного становлення майбутнього перекладача.

Ивашкевич Эрнест, Онуфриева Лиана. Готовность будущих переводчиков к выполнению профессиональной деятельности

\section{АННОТАЦИЯ}

Целью исследования была разработка концептуальной модели профессионального становления переводчика, а также проведение эмпири(c) Ivashkevych Ernest, Onufriieva Liana

DOI (article): https://doi.org/10.32626/2227-6246.2020-47.71-92 
ческого исследования с целью выяснения уровня готовности будущего специалиста к выполнению профессиональной деятельности.

Для решения поставленных в статье задач использовались следующие теоретические методы исследования: категориальный, структурно-функциональный анализ, систематизация, моделирование, обобщение, а также экспериментальный метод: констатирующий эксперимент.

В исследовании предложено концептуальную модель профрессионального становления будущего переводчика. Указано, что эта модель обязательно включает профессиональную готовность к выполнению деятельности. Готовность характеризуется разным характером взаимосвязей ее структурных компонентов (когнитивного - знание иностранного языка, лингвострановедческого - лингвострановедческая компетентность, реализационного - коммуникативные умения). Рассматривая готовность студента к кросскультурной коммуникации как совокупность отдельных значимых для специалиста показателей, мы (с учетом диагностических целей) определили характеристику различных уровней развития каждого из показателей готовности, которые рассматриваем в качестве критериальной основы для исследования феномена готовности студентов к осуществлению успешной кросскультурной коммуникации. Первый (когнитивный) показатель рассмотрен в контексте нашего исследования как разный уровень овладения иностранным языком. Фактически, когнитивный показатель готовности, по нашему мнению, содержит лингвострановедческую компетентность личности, а также коммуникативные умения специалиста и особенности их использования в переводческой деятельности.

Отмечено, что готовность специалиста к осуществлению профессиональной деятельности включает три компонента: а) мотивационную готовность; б) содержательную готовность; в) операциональную готовность. Несмотря на то, что профессиональная деятельность переводчика характеризуется аксиологической направленностью, указано, что готовность переводчика к осуществлению профессиональной деятельности содержит в своей структуре еще и четвертый компонент, а именно - «ценностную готовность».

Выводы. Потребность в творческой деятельности у студентов всех факультетов иностранной филологии является преимущественно высокой, а профессиональные качества, которые обуславливают фор-

(C) Ivashkevych Ernest, Onufriieva Liana DOI (article): https://doi.org/10.32626/2227-6246.2020-47.71-92 
DOI: https://doi.org/10.32626/2227-6246.2020-47 2020. ВиПУСК 47

мирование компонентов готовности к осуществлению переводческой деятельности, находятся на стадии становления, а именно: осознание необходимости доведения дела до логического завершения, владение базовыми средствами осуществления переводческой деятельности, ориентирование в межличностных отношениях. Также высокий уровень осуществления переводческой деятельности студентов каждой группы фиксируется на уровне не более 25\%, что в иелом свидетельствует о совершенно недостаточной профессионализации студентов.

Указано, что профрессиональное становление личности - это челостный, динамично развернутый во времени процесс, который характеризуется, прежде всего, формированием профессиональных намерений, затем - приобретением знаний и овладением умениями и навыками, и так до полной реализации себя в творческой профессиональной деятельности. Основным противоречием профессионального становления является, как правило, противоречие между сложившимися свойствами личности и объективными требованиями ведущей деятельности, значение которой состоит в том, что она во многом предопределяет дальнейшее развитие индивида как субъекта профессиональной деятельности. Реализуя себя в процессе ведущей деятельности, личность постепенно меняется, что приводит к перестройке мотивов профессиональной деятельности, формированию новых для человека личностных свойств, качеств и характеристик.

Ключевые слова: готовность к выполнению профессиональной деятельности, мотивационная готовность, содержательная готовность, операциональная готовность, профессиональное становление, концептуальная модель профессионального становления будущего переводчика.

Original manuscript received December 21, 2019

Revised manuscript accepted January 15, 2020

(C) Ivashkevych Ernest, Onufriieva Liana

DOI (article): https://doi.org/10.32626/2227-6246.2020-47.71-92 